\title{
Uniportal Video-Assisted Thoracoscopic Surgery in 263 Cases: A Retrospective Study
}

\author{
iki Yüz Altmış Üç Olguda Tek Port Video Yardımlı Torakoskopik Cerrahi: \\ Retrospektif Bir Çalışma
}

\author{
(1) Erkan Akar
}

University of Health Sciences, Bursa Yüksek Ihtisas Training and Research Hospital, Clinic of Chest Surgery, Bursa, Turkey

\section{Abstract}

Aim: Uniportal video-assisted thoracoscopic surgery (UVATS) is increasingly being used worldwide. In this study, we reviewed our early experiences with the use of UVATS in the treatment and the diagnosis of various thoracic diseases.

Methods: From January 2010 to January 2016, a single operator performed uVATS in 263 cases. Medical records of the patients were retrospectively reviewed.

Results: Of the 263 patients included in this study, 164 (62.4\%) were male and 99 (37.6\%) were female. The mean age of the study group was 51 (range: 17-93) years. Pleural biopsy was performed in 140 patients (88 males, 52 females) and diagnostic wedge resection in 123 patients (76 males, 47 females). The mean duration of wound drainage stay was three (range, 1-14) days; the mean duration of hospital stay was four (range, 2-19) days. Three patients suffered surgical complications including wound infection in two patients and air leak in one patient.

Conclusion: It is already known that uVATS is a technically safe and feasible method used for the diagnosis and treatment of various respiratory tract diseases and provides good postoperative results and this view is also supported by us.

Keywords: Thoracoscopy, uniportal, video-assisted thoracoscopic surgery, surgery
Öz

Amaç: Tek port video yardımlı torakoskopik cerrahisi (uVATS), dünyada gittikçe artan bir şekilde yapılmaktadır. Bu çalışmada, çeşitli göğüs hastalıklarının tedavisinde ve tanısında UVATS kullanımı ile ilgili erken deneyimlerimizi gözden geçirdik.

Yöntemler: Ocak 2010-Ocak 2016 Ocak tarihleri arasında, 263 olguya tek bir operatör ile UVATS yapıldı. Hastaların tıbbi kayıtları retrospektif olarak incelendi.

Bulgular: Çalışmaya dahil edilen 263 hastadan 164'ü $(\% 62,4)$ erkek, 99'u (\%37,6) kadındı. Çalışma grubunun yaş ortalaması 51 (17-93) yıl idi. Plevra biyopsisi; 88'i erkek ve 52'si kadından oluşan 140 olguda, tanısal wedge rezeksiyon, 76'sı erkek ve 47'si kadından oluşan 123 olguda yapıldı. Diren kalış süresi ortalama üç (1-14) gün, hastanede kalış süresi ortalama dört (2-19) gündü. İki hastada yara yeri enfeksiyonu ve bir hastada uzamış hava kacağı olmak üzere, üç hastada ameliyat komplikasyonu gelişti.

Sonuç: uVATS'ın, çeşitli solunum yolu hastalıklarının teşhis ve tedavisi için kullanılan, postoperatif iyi sonuçlar veren, teknik olarak güvenli ve uygulanabilir bir yöntem olduğu zaten bilinmekte olup biz de bu görüşü desteklemekteyiz.

Anahtar Sözcükler: Torakoskopi, tek port, video yardımlı torakoskopik cerrahisi, cerrahi

\section{Introduction}

Video-assisted thoracic surgery (VATS) has been performed from the late 1980s. Since then, the technique has widened its clinical indications for the past 20 years. Numerous previous studies have already proved that VATS is more advantageous for postoperative recovery, cosmetic results, and oncological outcomes compared to conventional thoracotomy $(1,2)$. Furthermore, as surgical experience in VATS has accumulated and instruments advanced, there have been attempts to perform uniportal VATS (UVATS) as an alternative for multiport VATS, with a few studies having reported the safety and feasibility of the former $(3,4)$.
Address for Correspondence/Yazışma Adresi: Erkan Akar

University of Health Sciences, Bursa Yüksek Ihtisas Training and Research Hospital, Clinic of Chest Surgery, Bursa, Turkey

E-mail: drerkanakar@hotmail.com ORCID ID: orcid.org/0000-0002-9113-8237

Received/Geliş Tarihi: 31 August 2017 Accepted/Kabul Tarihi: 13 November 2017
${ }^{1}$ Copyright 2018 by The Medical Bulletin of University of Health Sciences Haseki Training and Research Hospital
The Medical Bulletin of Haseki published by Galenos Yayinevi.

Telif Hakkı 2018 Sağlık Bilimleri Üniversitesi Haseki Eğitim ve Araştırma Hastanesi Haseki Tıp Bülteni, Galenos Yayınevi tarafindan basılmışıır. 
We reviewed our early experiences with the use of UVATS in the treatment of various thoracic diseases.

\section{Methods}

The study protocol was approved by the Ethics Committee of Bursa Yüksek ihtisas Training and Research Hospital (approval no: 2011-KAEK-25 2016/08-07). Hospital records of 263 patients, who underwent UVATS between January 2010 and January 2016, were retrospectively reviewed. The patients were evaluated with respect to age, gender, length of postoperative hospital stay, pathological diagnoses, postoperative complications, mortality, and morbidity (Table 1).

\section{Preoperative Evaluation}

The preoperative examinations were composed of thoracic computed tomography (CT) scan, spirometry, and arterial blood gas analysis. Positron emission tomography CT scan, brain magnetic resonance imaging, and bone scintigraphy were carried out if a malignant tumor was suspected. The preoperative indications for surgery included diagnosis and resection of mediastinal masses and pleural effusions, lung biopsy for interstitial pneumonia or pleural diseases, and management of pulmonary malignancy or benign conditions such as pneumothorax. UVATS was performed whenever surgeons found technically feasible.

\section{Surgical Technique}

The patients were placed in the lateral decubitus position after intubation with a double-lumen endotracheal tube. After one-lung ventilation, the location and length of the single incision was decided according to the indication for the surgery. The senior surgeons usually stood to the

\begin{tabular}{|c|c|c|}
\hline \multicolumn{2}{|l|}{ Variables } & \multirow{2}{*}{$\begin{array}{l}\text { Patients }(\mathbf{n}=\mathbf{2 6 3} \\
164(62.4 \%)\end{array}$} \\
\hline \multirow{2}{*}{ Gender $^{2}$} & male & \\
\hline & female & $99(37.6 \%)$ \\
\hline \multirow{2}{*}{ Age (years) ${ }^{1}$} & mean $\pm S D$ & 51 \\
\hline & minimum-maximum & $17-93$ \\
\hline \multirow{3}{*}{ Symptoms ${ }^{2}$} & coughing & $48(18.3 \%)$ \\
\hline & dyspnea & $126(47.9 \%)$ \\
\hline & dyspnea + chest pain & $89(33.8 \%)$ \\
\hline \multirow{2}{*}{ Surgical technique ${ }^{2}$} & pleural biopsy & $140(53.2 \%)$ \\
\hline & wedge resection & $123(46.8 \%)$ \\
\hline $\begin{array}{l}\text { Duration of postop. } \\
\text { hospital stay }\end{array}$ & mean \pm SD & 4 \\
\hline Day $^{1}$ & minimum-maximum & $2-19$ \\
\hline Postop. complications & wound infection ${ }^{2}$ & $\begin{array}{l}\text { Prolonged air } \\
\text { leak }{ }^{1}\end{array}$ \\
\hline
\end{tabular}

anterior side of the patient, and the assisting physicians behind the patient. A 2- to 3-cm-long incision was made in the fourth or fifth intercostal space (ICS), parallel to the anterior axillary line. When approaching the upper lobe, e.g. in cases of lung bullae, the incision was made in the $5^{\text {th }}$ ICS on the mid-axillary line. However, when approaching the lower lobe, the $6^{\text {th }}$ or $7^{\text {th }}$ ICS in the anterior axillary line was selected for the incision. If the patient had a previous wound scar from VATS or closed thoracotomy, we actively utilized that site despite the surgeon's discomfort. A wound protector was used without spreading the ribs in all patients. A $10 \mathrm{~mm}$, 30-degree video thoracoscope was routinely used for visualization, and articulated instruments were used for wedge resection from lung tissue.

The same pain control method was used in all patients. Bupivacaine $0.5 \%$ at a volume of 10-15 cc was injected on the parietal pleura, muscle, and subcutaneous layer before skin incision. Continuous-patient-controlled analgesia was not used for pain control. A single chest tube (28-F) was inserted into the end of the incision.

The decision to remove the chest tube was made when the lungs fully expanded and there was no pleural effusion on chest $X$-ray; there was no air leakage through the chest tube; and the amount of drainage was less than 100 cc per day. In the cases of pneumothorax, most patients had their chest tubes removed on postoperative day two and discharged on the same day after confirming with a postprocedural chest X-ray.

\section{Statistical Analysis}

Data were analyzed with the IBM SPSS 21 software package. Continuous variables were presented as median (range).

\section{Results}

This study included 263 patients, of whom 164 (62.4\%) were male and 99 (37.6\%) were female. The mean age of the whole group was 51 (range, 17-93) years. The most frequent symptoms were shortness of breath, chest pain, and cough. Pleural biopsy was performed in 140 patients (88 males, 52 females) and diagnostic wedge resection was performed in 123 patients (76 males, 47 females). The histopathological diagnoses included bullous-type lung disease $(n=66)$, granulomatous reaction $(n=38)$, metastatic carcinoma $(n=29)$, chondroid hamartoma $(n=12)$, chronic active pleuritis $(n=77)$, malignant mesothelioma $(n=5)$, and interstitial pneumonia $(n=11)$. Postoperative complications consisted of wound infection in two patients and prolonged air leak in one patient. The mean duration of wound drainage was three (range, 1-14) days and the mean duration of hospital stay was four (range, 2-19) days. The median length of intensive care unit stay was one (range, 0-4 days) day. There was no operative death (Table 2). 


\begin{tabular}{|l|l|l|}
\hline \multicolumn{3}{|c|}{ Table 2. Histopathologic diagnoses on the basis of gender } \\
\hline Pathological diagnoses & Male (n=164) & Female (n=99) \\
\hline Bullous lung & $49(29.9 \%)$ & $17(17.2 \%)$ \\
\hline Granulomatous disease & $21(12.8 \%)$ & $17(17.2 \%)$ \\
\hline Metastatic carcinoma & $16(9.8 \%)$ & $13(13.1 \%)$ \\
\hline Chondroid hamartoma & $3(1.8 \%)$ & $9(9.1 \%)$ \\
\hline Chronic pleuritis & $53(32.3 \%)$ & $24(24.2 \%)$ \\
\hline Lymphoma & $3(1.8 \%)$ & $2(2 \%)$ \\
\hline Malign mesothelioma & $16(9.8 \%)$ & $9(9.1 \%)$ \\
\hline Pneumonia & $3(1.8 \%)$ & $8(8.1 \%)$ \\
\hline *Numbers and \% values & & \\
\hline
\end{tabular}

biopsy, UVATS was used to diagnose mesothelioma ( $n=25)$, squamous cell carcinoma ( $n=13)$, breast cancer metastasis $(n=5)$, active chronic pleurisy $(n=77)$, and granulomatous reaction ( $n=20$ ). Kürkçüoğlu et al. (19) and Kurul et al. (20) obtained similar results with us in 47 and 23 patients, respectively, with pleural effusion.

With the development of minimally invasive surgical techniques, thoracoscopic wedge resections were frequently recommended for diagnostic purposes in interstitial lung diseases, solitary pulmonary nodules, and for therapeutic reasons in some lung pathologies including bullous diseases, metastasectomies, peripherally located hamartoma and pulmonary aspergilloma, especially because patient comfort is not impaired in the postoperative period (21).

UVATS also has a high capability in the diagnosis

\section{Discussion}

uVATS has a history spanning over more than 1 decade and, more recently, has become an increasingly popular approach for surgical treatment of thoracic diseases (5-8). The potential advantages of UVATS include less postoperative pain, fewer paraesthesias, and better cosmetic results (7-12). Nevertheless, uVATS still draws less attention because there are still some unclear points in terms of the safety in terms of mortality and morbidity associated with this technique.

Being the largest series of UVATS, this study repeats previous findings regarding the safety of uVATS $(5,6,8$ $10,12,13)$. It is clear that this technique can be used in selected patients with minimal in hospital mortality and morbidity.

Possible clinical advantages include the single-port approach with the potential of reducing postoperative chest pain due to the involvement of only one ICS and the avoidance of trocar use, which avoids intercostal nerve compression. It has been reported that fewer paraesthesias and less postoperative pain occurred with the single-port approach compared with the multiport approach $(14,15)$.

Evaluation of the undiagnosed pleural effusion, undiagnosed pulmonary nodules, interstitial lung disease, malignant tumor invasion, secondary cancer in lymph nodes, and staging of primary extrathoracic tumors are the known diagnostic indications for UVATS (16).

UVATS not only enables to take biopsies from any region but also to observe the entire pleural, mediastinal, and diaphragmal surfaces, and to obtain biopsies from the most problematic locations (5). Alar and Ozcelik (17) and Kara et al. (18) reported the facile and reliable application of UVATS with a low incidence of recurrence in patients with pleural effusion. In all of our 140 patients who could not be diagnosed by thoracentesis or closed pleural of nodular and interstitial lesions which could not be diagnosed with bronchoscopy and transthoracic biopsy. Kurul et al. (20) used UVATS in patients with single or multiple nodules imaged by $C T$ to diagnose malignant pathologies in four cases and benign pathologies in nine cases. We also applied uVATS in 42 cases and diagnosed 15 of the cases with malignant pathologies including squamous cell carcinoma $(n=6)$, adenocarcinoma $(n=3)$ and bronchoalveolar carcinoma $(n=1)$, and lymphoma $(n=5) ; 17$ cases were diagnosed with benign pathologies including granulomatous reaction $(n=15)$ and hamartoma $(n=12)$. After using UVATS in 15 patients with an interstitial pattern on $\mathrm{CT}$, we were able to diagnose granulomatous reaction $(n=2)$, sarcoidosis $(n=2)$, and squamous metaplasia (22).

UVATS can be performed in cases of primary or secondary spontaneous pneumothorax (23). One point requiring attention is the localization of all pulmonary air leaks, blebs and bullae by scanning. Another important point is the requirement of pleural abrasion or pleurectomy procedures after wedge resection, with or without air leakage, in order to ensure the removal of all blebs and bullae, overlooked or likely to recur post operatively, and thereby to prevent repetition of pneumothorax by means of the adhesion of the visceral and parietal pleura $(24,25)$. In our clinic, UVATS-assisted wedge resection and pleural abrasion were performed in 56 cases consulting with spontaneous pneumothorax. There were no incidences of recurrence within the 12-month follow-up of all cases.

Giant bullous lung disease large enough to fill at least $1 / 3$ of a hemithorax, presenting as a complication of emphysema, can be operated with UVATS. Development of symptoms, such as shortness of breath related to the bulla, pneumothorax, infection, empyema, and massive haemoptysis are the indications for surgery (25). The place of preventive surgery in asymptomatic patients 
is a subject of debate, and the advantages and risks of surgery need to be carefully considered. When there are problems related with the patient and the surgical treatment, selecting the right patient, and evaluating the likely postoperative complications are important issues (25). When selecting a surgical procedure, a surgeon has to consider the factors least likely to impair the current respiratory function of the patient, and choose a procedure with the best outcomes. UVATS is therefore preferred to open surgery for patients with limited respiratory function. Here the aim is to excise the bulla without causing air leakage and to achieve the expansion of the lung (25). Ten of our patients with giant bullous lung disease suffered shortness of breath adversely affecting daily life. In order to prevent or minimize the formation of air leakage, staple line reinforcement was used and the bullae were excised followed by pleural abrasion. No recurrence was observed during a mean period of 16 months of follow-up. Linear and circular stapling devices enable surgeons to perform minimally invasive surgery allowing simultaneous stapling and sealing of the tissue, thus giving surgeons the ability to divide and transect a variety of tissues with ease. However, there are two major drawbacks of the stapling technology: the development of staple line bleeding and leaks. These potential complications can lead to significant postoperative morbidity and even mortality, which were not experienced during the relatively shortened course of uVATS.

\section{Study Limitations}

The limitations of this study are its descriptive and retrospective nature. Moreover, our study did not analyze postoperative pain, cosmetic factors, long-term survival outcomes, and quality of life. We did not include both groups of patients because we are at the beginning stage of lung cancer treatment with UVATS, and we also evaluated our case with sympathectomy in another study.

\section{Conclusion}

UVATS is technically safe and feasible with good postoperative outcomes in selected patients.

\section{Ethic}

Financial Disclosure: The authors declared that this study received no financial support.

\section{References}

1. Yan TD, Black D, Bannon PG, McCaughan BC. Systematic review and meta-analysis of randomized and nonrandomized trials on safety and efficacy of video-assisted thoracic surgery lobectomy for early-stage non-small-cell lung cancer. J Clin Oncol 2009;27:2553-62.

2. Kim K, Kim HK, Park JS, et al. Video-assisted thoracic surgery lobectomy: single institutional experience with 704 cases. Ann Thorac Surg 2010;89:2118-22.
3. Rocco G. Single-Port Video-Assisted Thoracic Surgery (Uniportal) in the Routine General Thoracic Surgical Practice. Oper Tech Thorac Cardiovasc Surg 2009;14:326-35.

4. Yang HC, Cho S, Jheon S. Single-incision thoracoscopic surgery for primary spontaneous pneumothorax using the SILS port compared with conventional three-port surgery. Surg Endosc 2013;27:139-45.

5. Rocco G, Martin-Ucar A, Passera E. Uniportal VATS wedge pulmonary resections. Ann Thorac Surg 2004;77:726-8.

6. Rocco G, Brunelli A, Jutley $R$, et al. Uniportal VATS for mediastinal nodal diagnosis and staging. Interact Cardiovasc Thorac Surg 2006;5:430-2.

7. Ng CS, Kim HK, Wong RH, Yim AP, Mok TS, Choi YH. Singleport videoassisted thoracoscopic major lung resections: experience with 150 consecutive cases. Thorac Cardiovasc Surg 2016;64:348-53.

8. Wang BY, Liu CY, Hsu PK, Shih CS, Liu CC. Single-incision versus multiple-incision thoracoscopic lobectomy and segmentectomy: a propensity-matched analysis. Ann Surg 2015;261:793-9.

9. Gonzalez-Rivas D, Paradela M, Fernandez R, et al. Uniportal video-assisted thoracoscopic lobectomy: two years of experience. Ann Thorac Surg 2013;95:426-32.

10. Hsu PK, Lin WC, Chang YC, et al. Multiinstitutional analysis of single-port video-assisted thoracoscopic anatomical resection for primary lung cancer. Ann Thorac Surg 2015;99:1739-44.

11. Wang GS, Wang Z, Wang J, Rao ZP. Uniportal complete video-assisted thoracoscopic lobectomy with systematic lymphadenectomy. J Thorac Dis 2014;6:1011-6.

12. Rocco G, Martucci N, La Manna C, et al. Ten-year experience on 644 patients undergoing single-port (uniportal) video-assisted thoracoscopic surgery. Ann Thorac Surg 2013;96:434-8.

13. Rocco G. VATS lung biopsy: the uniportal technique. Multimed Man Cardiothorac Surg 2005;2005(121):mmc ts.2004.000356.

14. Tamura M, Shimizu Y, Hashizume Y. Pain following thoracoscopic surgery: retrospective analysis between singleincision and three-port videoassisted thoracoscopic surgery. J Cardiothorac Surg 2013;8:153.

15. Mier JM, Chavarin A, Izquierdo VC, Fibla JJ, Molins L. A prospective study comparing three-port video-assisted thoracoscopy with the singleincision laparoscopic surgery (SILS) port and instruments for the video thoracoscopic approach: a pilot study. Surg Endosc 2013;27:2557-60.

16. Okur E, Halezeroğlu S. Video-assisted thoracoscopy. Turkiye Klinikleri J Int Med Sci 2006;2:42-47.

17. Alar T, Ozcelik C. Single-incision thoracoscopic surgery of pleural effusions for diagnosis and treatment. SurgEndosc 2013;27:4333-36.

18. Kara M, Alzafer S, Okur E, Halezeroglu S. The use of single incision thoracoscopic pleurectomy in the management of malignant pleural effusion. Acta Chir Belg 2013;113:270-74.

19. Kürkçüoğlu C, Karaoğlanoğlu N, Eroğlu A, Ünlü M. Video assisted pleural effusions: evaluation of 47 cases. Turkish J Thorac and Cardiovasc Surg 2000;8:712-4. 
20. Kurul IC, Sayan M, Aytekin I, et al. Preferred approach in diagnosis and treatment: VATS. Gazi Med J 2012;23:10-2.

21. Fell SC, Kirby TJ. Limited pulmonary resection. In: Pearson F.G, Coopere J.D, Deslauriers J, Ginsberg R.J, Hiebert C.A, Patterson G.A, Urschel H.C; eds. ThoracicSurgery. 2nd ed. Philadelphia: Churchill Livingstone 2002;1002-04.

22. Karadayi S, Sahin E. History of the Endoscopic Interventions in Thoracic Surgery. J ThorSurg-Special Topics 2009;2:1-5.

23. Yang Y, Dong J, Huang Y. Single-incision versus conventional three-port video-assisted surgery in thetreatment of pneumothorax: a systematic review and meta-analysis. Interactive CardioVascular and Thoracic Surgery 2016;1-7.

24. Attaran S, Bille A, Karenovive W, Lang-Lazdunski L. Videothoracoskopic repair of diaphragm and pleurectomy/ abrasion in patients with catamenial pneumothorax: a 9 year experience. Chest 2013;143:1066-9.

25. Bayram AS, Erol MM, Kaya FN, Özcan M, Köprücüoğlu M, Gebitekin C. Thoracoscopic bullectomy and pleural abrasion in the treatment of primary spontaneous pneumothorax. Tuberk Toraks 2008;56:291-5. 